Sf存 Universidad

辛: de Alcalá

\title{
BIBLIOTECA
}

Document downloaded from the institutional repository of the University of Alcala: http://dspace.uah.es/dspace/

This is a postprint version of the following published document:

Andivia, E. et al., 2019. Rooting big and deep rapidly: the ecological roots of pine species distribution in southern Europe. Trees, 33(1), pp.293-303.

Available at http://dx.doi.org/10.1007/s00468-018-1777-x

(C) 2018 Springer Verlag
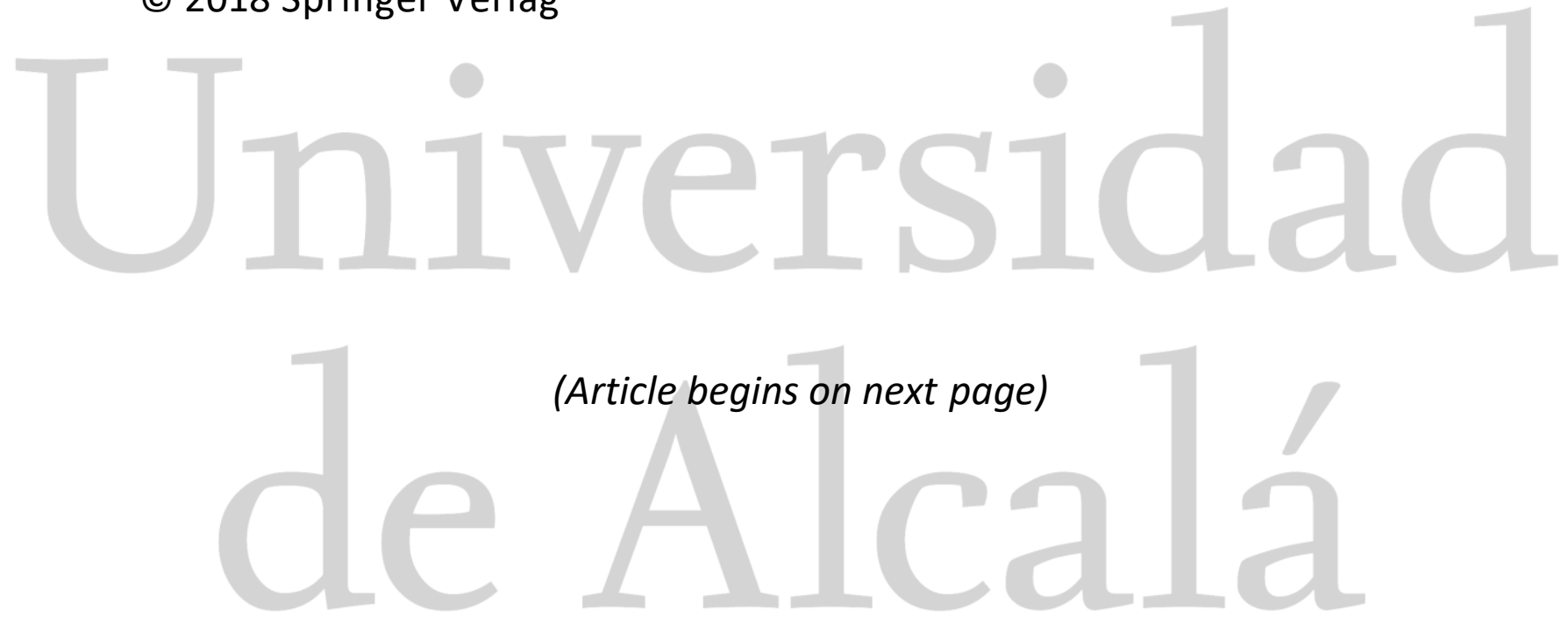

(Article begins on next page)
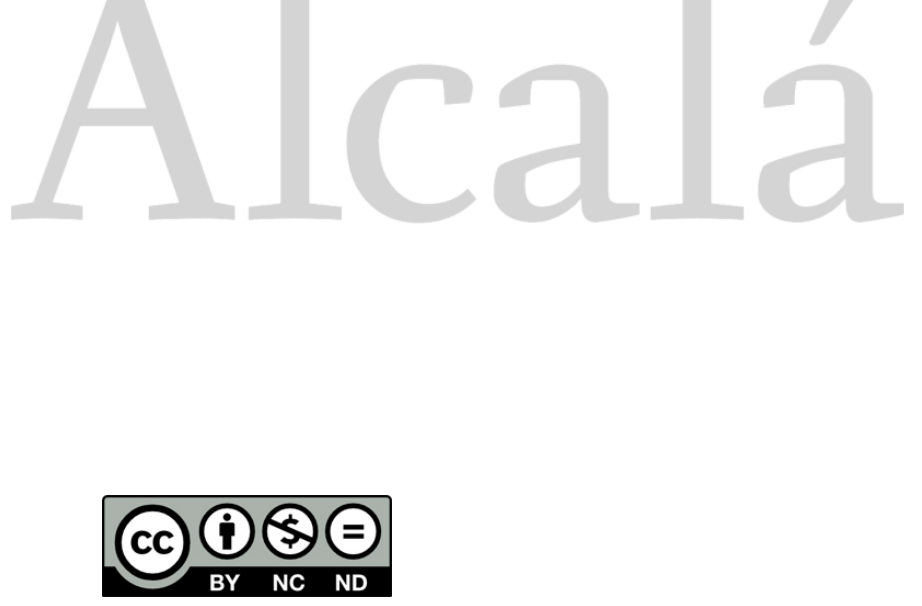

This work is licensed under a

Creative Commons Attribution-NonCommercial-NoDerivatives

4.0 International License. 


\section{Rooting big and deep rapidly: the ecological roots of pine species distribution}

\section{2 in southern Europe}

3

4 Enrique Andivia ${ }^{1}$, Paolo Zuccarini ${ }^{2,3}$, Beatriz Grau $^{2}$, Felicidad de Herralde ${ }^{2}$, Pedro Villar5 Salvador ${ }^{1}$, Robert Savée, *

6

1. Forest Ecology and Restoration Group, Departmento de Ciencias de la Vida, Universidad de

Alcalá, Apdo. 20, Alcalá de Henares, Madrid 28805, Spain

2. Plant Science Area -IRTA- Institut de Recerca i Tecnologia Agroalimentaries, Torre Marimon, C-59, Km 12.1, Caldes de Montbui, Barcelona 08140, Spain

3. CREAF, Campus de Bellaterra, Universitat Autònoma de Barcelona, Cerdanyola del Vallès, Barcelona 08193, Spain

* Author for correspondence: Robert Savé, Plant Science Area -IRTA- Institut de Recerca i Tecnologia Agroalimentaries, Torre Marimon, C-59, Km 12.1, Caldes de Montbui, Barcelona 08140, Spain. Tel: +34 934674040, ext. 1326. Email: robert.save@irta.cat

Emails of other authors: EA (e.andivia@gmail.com), PZ (p.zuccarini@creaf.uab.cat), BG (beatriz.grau.s@gmail.com),FdeH (felicidad.deherralde@irta.cat), PVS (pedro.villar@uah.es).

ORCID number: EA (0000-0002-9096-3294) 
Author Contribution Statement: RS, FdH and PV designed the study, experiment setup and data collection was made by BG, FdH and PZ, data was analyzed by EA and PZ, first draft was written by EA and PV, final edition was done by all authors.

\section{Acknowledgments}

Research was supported by the projects Life MEDACC, AGL2011-24296 ECOLPIN (MICIIN), CGL2014-53308-P (SERAVI), Centres CERCA of Generalitat de Catalunya and the network REMEDINAL 3 (S2013/MAE-2719) of the CAM. EA was supported by postdoctoral grant "Ayudas para contratos para la formación postdoctoral" (FPDI-2013-15573) from the Spanish Government. We thank Laia Serra and Christian Morales for their technical assistance and Verónica Cruz-Alonso for figure preparation.

\section{Conflict of Interest}

The authors declare that they have no conflict of interest.

\section{Data availability}

The datasets generated during and/or analysed during the current study are available from the corresponding author on reasonable request. 


\section{Abstract}

Root properties can influence plant drought resistance, and consequently plant species distribution. Root structure strongly varies across biomes partly as a result of phylogeny. However, whether the spatial distribution of phylogenetically close plant species is linked to differences in root properties remains unclear. We examined whether root properties mediate the strong correlation between summer drought intensity and the spatial segregation of pine species native to southern Europe. For this, we compared the seedling root growth and structure of five ecologically distinct pine species grown in 360L rhizotrons for 19 months under typical hot and dry Mediterranean conditions. We studied the mountain and boreo-alpine pines Pinus sylvestris and Pinus nigra, and the Mediterranean pines Pinus pinaster, Pinus pinea and Pinus halepensis. Mediterranean pines formed deep roots faster than mountain pines, their shoots and roots grew faster and had higher root growth, especially $P$. halepensis, at low air temperature. By the end of the study, Mediterranean pines had larger root systems than mountain pines. Neither distribution of root mass with depth nor root-to-shoot mass ratio varied significantly among species. Across species, minimal annual rainfall to which species are exposed in their range related negatively to root growth but positively to specific root length and the time needed for roots to reach a depth of $40 \mathrm{~cm}$. This study highlights the importance of root growth as a driver of pine distribution in southern Europe and suggests that rapidly producing a large, deep root system may be a key attribute for pines to colonize dry Mediterranean locations.

Keywords: Drought resistance; Pinus; Rhizotron; Root growth; Root structure; Rooting depth; Specific root length

Key message: The rapid production of a large, deep root system during seedling establishment is critical for pines to colonize dry Mediterranean locations 


\section{Introduction}

Water stress constrains plant life in many terrestrial ecosystems (Vicente-Serrano et al. 2013). Plants show a wide variety of adaptations to survive in dry ecosystems (Levitt 1980; Chaves et al. 2003; Brodribb et al. 2014). Roots vary widely in structure among plant species, and several root properties have been related to drought resistance of plants (Padilla and Pugnaire 2007; Alsina et al. 2011; Comas et al. 2013; Brunner et al. 2015). The size of the root system and rooting depth determine the plant's ability to access deep soil moisture reserves during dry periods (Schulze et al. 1996). Across species, the size of the root system, rooting depth and root hydraulic conductance increase with the size of growth forms (Canadell et al.1996; Schenk and Jackson 2002; De Herralde et al. 2010). However, for a specific growth form, species inhabiting water-limited environments tend to have deeper roots than their mesic counterparts (Jackson et al. 1996).

The proportion of mass allocated to roots has also been related to plant drought resistance. The proportion of root mass relative to either shoot mass $(\mathrm{R} / \mathrm{S})$ or entire plant mass (root mass fraction, RMF) are indicators of the potential balance between water uptake and evaporative capacity of a plant (Grossnickle 2012). Globally, R/S (Mokany et al. 2006), RMF (Poorter et al. 2012b) and the relative distribution of root mass in depth (Schenk and Jackson 2002) usually increase with aridity. In addition, plants species differ substantially in fine root production (Ostonen et al. 2007; Valverde-Barrantes et al. 2017). Fine root growth is often studied using the proxy variable of specific root length (SRL), defined as the length of roots per root mass unit (Ostonen et al. 2007). High-SRL root systems have a large root surface and consequently high capacity to take up soil resources (Comas et al. 2013). In a global review of studies of fine-root traits, SRL was greater in plants from cold and temperate climatic areas than in plants from arid and tropical areas (Freschet et al. 2017). Fast growing woody plants, 
which have high nutrient demand, grow more high-SRL roots than slow growing plants (Reich et al. 1998; Comas and Eissenstat 2004; Hernández et al. 2010).

The seedling stage is a major bottleneck in the life history of plants and consequently in population dynamics (Pulido et al. 2010). Rooting depth determines the capacity of seedlings to access deep soil layers (Padilla and Pugnaire 2007), which usually hold stable water reserves during the dry season (Brum et al. 2017). This fact likely explains why the ability of seedlings in seasonal dry climates to survive their first dry season depends on root system size and rooting depth (Grossnickle 2005; Padilla and Pugnaire 2007; Villar-Salvador et al. 2012). Plants can achieve a deep and extensive root system either by starting to grow early in the wet season (De Luis et al. 2008) and/or by growing rapidly during the wet season (Holmgren et al. 2006; Stella and Battles 2010). Root growth in the wet season depends on soil and air temperature. Response of root growth to temperature varies among species (Lyr 1996; Pregitzer et al. 2000). Most plant species slow root growth greatly when soil temperature is $<10^{\circ} \mathrm{C}$ and root growth cessation occurs at $2-6^{\circ} \mathrm{C}$ (Alvarez-Uria and Körner 2007). Species differences in the response of root growth to temperature seems to be related to the temperature to which species are exposed in their range (Lyr 1996).

The spatial segregation of native pine species in southern Europe is correlated with summer drought and winter temperature (Barbero et al. 1998). Pinus nigra J.F. Arnold and $P$. sylvestris L. (hereafter referred to as mountain and boreo-alpine pines) inhabit cold winter sites in the high mountains of southern Europe, where rainfall is high and summer drought is mild and short. At these locations, cold is the main limitation for plant life (Barbero et al. 1998). In contrast, Pinus halepensis Mill., Pinus pinaster Ait., and Pinus pinea L. (hereafter referred to as Mediterranean pines) thrive in low- and mid-altitude locations in a typical Mediterranean climate, where winter is mild-to-cool and humid, while the summer is hot and dry (Barbero et al. 1998). At these sites, summer water stress is the main limiting factor for plant life (Mitrakos 
1980). The spatial segregation of these pine species can be explained in part by their capacity to withstand frost events. Pinus halepensis, $P$. pinea and to a lesser extent $P$. pinaster are less frost-tolerant than the high-mountain pines $P$. sylvestris and P. nigra (Climent et al. 2009; Fernández et al. 2017; Toca et al. 2017). However, the fact that P. sylvestris and P. nigra do not occur at low-altitude locations where summers are dry and hot could be explained by a lower capacity to survive water stress than Mediterranean pines in the early life stages (SalazarTortosa et al. 2018).

The objective of this study was to compare the growth and structure of root systems of five ecologically distinct pine species native to the Iberian Peninsula (P. sylvestris, $P$. nigra, $P$. pinaster, $P$. pinea and $P$. halepensis) under lowland Mediterranean conditions. For this, we grew seedlings of these pine species in a common garden experiment simulating the low precipitation and high temperature regime typical of low- and mid-altitude Mediterranean location. Plants were grown in 360-L rhizotrons to avoid small rooting volume constraints (Poorter et al. 2012a), and we analyzed the root dynamics and structure for 19 months. We hypothesized that Mediterranean pines will grow faster a larger and deeper root system, showing higher SRL than mountain and boreo-alpine pines under these experimental conditions. This study will contribute to explain why mountain and boreo-alpine pines species fail to colonize low altitude Mediterranean environments.

\section{Material and methods}

\subsection{Experimental setup and plant growth}

Seeds of the five pine species were collected from populations in the southern part of the Iberian Range, eastern Spain (see Table S1 for locations and their environmental details). This region covers around $8500 \mathrm{~km}^{2}$ and natural populations of all studied species segregate along an altitudinal gradient from 650 to $2050 \mathrm{~m}$ a.s.l. (Blanco et al. 1998). Seeds were seeded in 
February 2012 and seedlings were cultivated in trays (190/300-45, Plasnor, Spain) of $300 \mathrm{ml}$.

143 Growing medium was fertilized peat (White 420 F6, Kekkilä, Finland) containing $0.8-1 \mathrm{~kg} / \mathrm{m}^{3}$

144 of slow-release fertilizer NPK 16-10-20. Seedlings were initially grown in a greenhouse of the

145 Centro Nacional de Recursos Genéticos Forestales "El Serranillo" (Guadalajara, Spain) until 146 late March 2012, then transported to the IRTA in Caldes de Montbui (Barcelona, Spain), where 147 the rest of the study was performed. From late March to early June 2012, seedlings were kept 148 inside a greenhouse and periodically watered until transplanted to rhizotrons. In early June 2012, six four-month-old seedlings per species were transplanted into 30 rhizotrons ( 1 seedling per rhizotron; rhizotron dimensions were height: $1.2 \mathrm{~m}$, width: $0.5 \mathrm{~m}$ and depth: $0.6 \mathrm{~m}$ ) filled with washed river sand. The side and rear walls of the rhizotrons were made of galvanized iron sheets, while the front wall was glass, which was covered by reflective plastic to avoid radiation (light and temperature) at root level. The rhizotrons were placed inside an open greenhouse tunnel, which reduced ambient photosynthetic photon flux density by $30 \%$. At the time of transplanting seedling height and diameter $( \pm \mathrm{SE})$ were: $11.4 \pm 0.7 \mathrm{~cm}$ and $2.3 \pm$ $0.1 \mathrm{~mm}$ for $P$. halepensis; $15.9 \pm 0.2 \mathrm{~cm}$ and $3.1 \pm 0.2 \mathrm{~mm}$ for $P$. pinea; $14.7 \pm 1.3 \mathrm{~cm}$ and 2.8 $\pm 0.1 \mathrm{~mm}$ for $P$. pinaster; $8.7 \pm 0.2 \mathrm{~cm}$ and $2.1 \pm 0.1 \mathrm{~mm}$ for $P$. nigra; and $7.4 \pm 0.2 \mathrm{~cm}$ and 2.5 $\pm 0.1 \mathrm{~mm}$ for $P$. sylvestris, respectively. Seedlings were water-supplied with approximately the average rainfall rate of Caldes de Montbui (altitude: $203 \mathrm{~m}$ a.s.1.). This location has a typical Mediterranean climate with a mean temperature of $15.5^{\circ} \mathrm{C}$ and a mean annual rainfall of 633 $\mathrm{mm}$. Water was supplied daily during the first month and then every 2-3 days thereafter. The cumulative amount of water supplied per plant during the study was 572 L. Soil volumetric water content (VWV, \%) was measured every 2 weeks using a 70-cm frequency domain reflectometry probe (Diviner 2000, Sentek Sensor Technologies Stepney, Australia). The accession tube was inserted before planting of seedlings, and soil moisture was measured at 10- 
of 0-20, 20-40 and 40-70 cm. Mean VWC increased with depth and was higher in mountain and boreal pines than in Mediterranean pines (Figure S1). In general, soil VWC decreased slightly over time in the depth layers of 20-40 and 40-70 cm, whereas it fluctuated without any clear pattern in the $0-20 \mathrm{~cm}$ layer.

Air temperature was measured daily using electronic sensors (PASSRHT, Decagon Devices, Washington, USA) placed next to the rhizotrons. Mean air temperature during the study was $16.6{ }^{\circ} \mathrm{C}$, fluctuating between $30.3{ }^{\circ} \mathrm{C}$ in mid-August 2012 and $3.2{ }^{\circ} \mathrm{C}$ in early December 2012 (Figure S2). The lowest air temperature was $-2.6^{\circ} \mathrm{C}$ in late February 2013; the highest temperature was $40.9^{\circ} \mathrm{C}$ in late July 2012 .

\subsection{Root and shoot measurements}

Root elongation measurement was initiated after seedlings were established in early October 2012 and were taken every two weeks until May 2014. The length of the visible roots growing against the rhizotron wall was measured in four soil layers, each of which was $20-40 \mathrm{~cm}$ thick: these layers covered depths of $0-20,20-40,40-80$, and $80-110 \mathrm{~cm}$. These layers were photographed with a digital camera, and root length was determined using WinRHIZO (Regent Instruments, Canada).

At the end of the experiment in early June 2014, plants were extracted from the rhizotrons by gently removing the growing medium with water. Plants were separated into shoots and roots and washed with tap water. The roots were cut at three depth layers $(0-40,40-$ 80 and $80-120 \mathrm{~cm}$ ), scanned and their length quantified using WinRHIZO. Then all plant fractions were dried at $60{ }^{\circ} \mathrm{C}$ until constant weight. SRL was calculated as the ratio between total root length and total root mass, while R/S was calculated by dividing root mass by shoot mass.

Shoot growth was monitored by periodically measuring stem height and diameter, which was measured at $1 \mathrm{~cm}$ from the ground. Both measurements were performed at planting 
and on the following days after transplanting: 336 (18 June 2013), 456 (16 October 2013), 545 (13 January 2014), 618 (26 March 2014) and 686 (02 June 2014). We also used the relative growth rate (RGR) as a surrogated of plant growth. RGR was calculated as:

$$
R G R=\frac{\ln \left(m_{t 2}\right)-\ln \left(m_{t 1}\right)}{t 2-t 1}
$$

where $m$ is the plant mass at the time of transplantation into the rhizotron $(t 1)$ and at the end of the experiment $(t 2)$. The mass at $t 1$ was measured on 10 seedlings per species randomly sampled after drying at $60^{\circ} \mathrm{C}$ for $48 \mathrm{~h}$.

\subsection{Data analysis}

Differences in height and diameter growth rates between species were assessed using a linear mixed model in which the random effect was individuals and the fixed effect was the interaction between species factor and the covariate time (days since planting). Significant differences $(\mathrm{P}<0.05)$ in the model slope meant that growth rates were different among species.

The effect of species on root and shoot measurements after harvesting were analyzed using one-way ANOVA. The response variables were shoot mass, total root mass, total root length, R/S, and SRL. We also evaluated the effect of species on the total root mass, and on the root mass proportion at the three different soil layers (0-40, 40-80 and 80-120 cm). Significant differences between species were evaluated using a Tukey HSD test $(\mathrm{P}<0.05)$.

Root elongation rate was analyzed using a Generalized Additive Mixed Model (GAMM) in which the random factor was individuals, the smoothed term was time (days since planting), and the fixed effect was species. We fitted four different GAMM models, one for each soil layer. To evaluate whether species had a significant effect on root elongation, we compared the model with a model in which species was omitted. If the difference between the two models was $\leq 2$ in the corrected Akaike's information criterion (AICc), then the simpler model was selected (Burnham and Anderson 2002). 
We also analyzed the effect of air temperature on species root growth. For this, root length of all soil layers was added up to yield the total root length per seedling and measurement date. Then, we calculated root length increment $\left(\mathrm{mm} \mathrm{day}^{-1}\right)$ as the difference in root length between two consecutive measurement dates divided by the number of days between both measurements. As the magnitude of root length increment greatly differs among species, it was species-scaled to 0-1 values (hereafter RLI). We used a linear mixed model to evaluate whether the relationship between RLI and temperature was species idiosyncratic. This model included the interaction between species and temperature as fixed effect, and each individual as random term. First, we compared -based on the AICc- this model with a model in which temperature was considered as a second order polynomial. The selected model in this step was then compared with a model in which species factor was dropped.

To assess whether species influenced root growth speed through depth, we quantified the time taken by each individual to reach a depth of $40 \mathrm{~cm}$ after transplanting into the rhizotrons. We considered that the roots of an individual reached a depth of $40 \mathrm{~cm}$ when the roots became visible in the layer at a depth of $40-50 \mathrm{~cm}$. Data were analyzed using one-way ANOVA in which the response variable was the time taken by roots to reach a depth of $40 \mathrm{~cm}$. We used linear regression to analyze whether inter-species differences in root properties were related to climatic conditions normally encountered by the species in their distribution range in the Iberian Peninsula. We used distribution data for continental Spain from the third Spanish Forest Inventory, which analyzed adults and saplings of all woody species in plots distributed over forest ecosystems according to a $1-\mathrm{km}^{2}$ grid. We selected those plots classified as natural pine forests based on the Spanish Regions of Provenance (Ruiz-Benito et al. 2012). Then we selected the plots showing saplings for each studied pine species. Climatic variables were calculated from a map with $1-\mathrm{km}^{2}$ spatial resolution (Gonzalo 2008) for each species, we chose the $2.5 \%$ percentile values for mean annual precipitation. This value represents the mean 
annual rainfall in the $2.5 \%$ most arid locations in the range of each species. All statistical analyses were performed using $R$ 3.2.5.

\section{Results}

\subsection{Aboveground growth}

At the end of the experiment on day 728 after planting, $P$. halepensis, $P$. pinea and $P$.pinaster showed greater shoot mass than $P$. nigra and $P$. sylvestris (Figure S3). We found a significant interaction between species and time (days since planting) on seedling stem height and diameter (both $\mathrm{P}<0.001$ ). Pinus halepensis showed a significantly larger diameter and faster height growth (higher interaction slope) than the other pine species, whereas $P$. sylvestris showed the slowest growth (Figure S4). Pinus pinaster showed faster height growth than P. pinea, P. nigra and $P$. sylvestris, while no significant differences were found between $P$. nigra and $P$. pinea. Similarly, no significant differences in diameter growth rate were observed among $P$. pinea, $P$. pinaster and P. nigra. P. halepensis also showed the highest RGR and P. nigra and P. sylvestris showed the lowest RGR, while P. pinea and P. pinaster had similar RGR (Figure S5).

\subsection{Belowground growth}

At the end of the experiment, $P$. halepensis, $P$. pinea and $P$. pinaster showed greater root mass than P. nigra and $P$. sylvestris (Figure 1a). However, species did not significantly differ in R/S. Root mass varied with depth in the same way that total root mass did (Figure 1). Pinus nigra and P. sylvestris showed the smallest root mass at all depths. However, the distribution of root mass with depth did not differ between species. Differences among species affected the mass of roots produced in the soil profile but not the relative distribution of root mass with depth. Total root length showed a similar pattern as root mass. Pinus halepensis and P. pinaster had longer roots than P. nigra and P. sylvestris; the latter two species had roots of similar length 
(Figure 2a). Species SRL showed the opposite trend as root length and mass, with P. sylvestris showing the largest SRL and P. halepensis the smallest (Figure 2b).

Root length increased over time to different extents among the various Iberian pine species (Figure 3, Table S2). Pinus halepensis showed the greatest capacity to quickly colonize soil layers (Figure 3), especially the layer at $0-20 \mathrm{~cm}$, followed by $P$. pinaster and $P$. pinea. In general, these three species showed the greatest root length increase in each soil layer, whereas P. sylvestris showed the smallest and slowest increase in root length (Figure 3). Root length in P. nigra increased more than in P. sylvestris but less than in Mediterranean pines except in the 0-20-cm layer, where $P$. nigra showed the lowest increase in root length of all five pine species. From day 385 onwards, $P$. pinea showed the longest roots in the layers at depths of 20-40 and 40-80 cm. Roots of P. nigra and P. sylvestris lengthened more slowly towards the end of the experiment than initially, except for soil layer at a depth of 80-110 cm, where growth remained active (Figure 3). The Mediterranean pines, in contrast, showed active growth across all the soil depth layers. Roots lengthened at similar rates across all species in the soil layer at $80-110 \mathrm{~cm}$ (Table S2).

Scaled root length increment (RLI) showed a quadratic and idiosyncratic species response to temperature (Table S3). RLI monotonically increased in P. nigra and P. sylvestris (Figure 4). $P$. pinaster and $P$. pinea showed a similar response to mountain pines but reaching constant values around $20^{\circ} \mathrm{C}$. On the contrary, $P$. halepensis showed maximum RLI values at low temperatures and then decreased with temperature (Figure 4). RLI values at $7^{\circ} \mathrm{C}$ was highest in $P$. halepensis $(0.18 \pm 0.03)$ followed by $P$. pinea and $P$. pinaster $(0.04 \pm 0.03$, for both species). P. sylvestris and P. nigra showed the lowest scaled RLI values $(0.02 \pm 0.03$ and 0.01 \pm 0.03 , respectively). 
according to the trend: $P$. halepensis $<\mathrm{P}$. pinea and $P$. pinaster $<P$. nigra $(150$ days after $P$. halepensis $)<P$. sylvestris (180 days after P. halepensis) (Figure 5).

\subsection{Relationship between root characteristics and rainfall in the distribution range}

Root mass at the end of the experiment and the stem diameter growth rate of each species correlated negatively with the $2.5 \%$ smallest annual precipitation in the natural range of that species (Figure 6). In contrast, SRL and the time for roots to reach a depth of $40 \mathrm{~cm}$ correlated positively with the $2.5 \%$ smallest annual rainfall in the natural range (Figure 6 ).

\section{Discussion}

Juveniles of pine species differ in how rapidly they grow during establishment and consequently in the final size of their root systems and shoots. Interestingly, root differences among species correlate strongly with the precipitation in the driest areas of the species range. In accordance with our hypothesis, seedlings of the Mediterranean pine species, which are exposed to high drought stress in their range (especially $P$. halepensis), show greater ability to rapidly colonize the soil profile and produce larger root systems than the seedlings of the mountain and the boreo-alpine pines under typical lowland Mediterranean conditions. These root differences may drive drought survival (Grossnickle 2005; Padilla and Pugnaire 2007; Villar-Salvador et al. 2012). Consistent with this suggestion, survival and growth of $P$. nigra and $P$. sylvestris was significantly lower than $P$. halepensis survival in a common garden experiment in a dry hot Mediterranean location (Salazar-Tortosa et al. 2017; Salazar-Tortosa et al. 2018). Therefore, this study provides new insights into the functional basis of the latitudinal and altitudinal spatial segregation of pines in southern Europe. However, low field survival and growth of mountain and boreo-alpine pines might be also explained by poor physiological performance under water stress conditions (Salazar-Tortosa et al. 2017; Salazar-Tortosa et al. 2018). In addition, the use 
of one provenance per species requires some caution when generalizing our results. Because we used provenances from the southern dry edge of the range of the mountain and boreo-alpine species, which are more drought resistant than northern and mesic provenances (Richter et al. 2012; Matías et al. 2014), it is unlikely that the lower growth of these pine species compared to the Mediterranean pines is biased by provenances selection. Future studies, however, should evaluate provenances differences in root growth. In water-limited ecosystems, seedling mortality due to water stress during the first dry season is a bottleneck for forest regeneration (Castro et al. 2004; Pulido et al. 2010). Resistance of seedlings to drought relies on adaptations that increase water uptake and/or reduce water loss during dry periods (De Micco and Aronne 2012; Brunner et al. 2015). In the present study, Mediterranean pines colonized through soil depth more rapidly, as evidenced by shorter time to reach a depth of $40 \mathrm{~cm}$ (Figure 5) and showed the fastest aboveground growth, growing larger than mountain pines at the end of the experiment. This indicates that seedling establishment under Mediterranean climate conditions depends on how rapidly the root system colonizes the soil profile. Similar to our findings, Climent et al. (2011) observed that $P$. pinaster, $P$. pinea and $P$. halepensis grew faster than $P$. nigra and $P$. sylvestris after 32 weeks of growth in 7-L containers. Higher shoot growth rate leads to greater foliage biomass and higher photosynthesis (Cuesta et al. 2010). This greater C assimilation will support the growth of new organs during the wet season, triggering a positive feedback loop in which shoot and root growth support each other (Burdett 1990; Villar-Salvador et al. 2012). In addition, Mediterranean pines, especially P. halepensis achieved maximum root growth potential at lower air temperature than mountain and boreo-alpine pines (Figure 4). Maximizing root elongation during the cool and wet season can facilitate seedling establishment before the summer drought, the most limiting season for seedling life in Mediterranean climates (Castro et al. 2004; Pulido et al. 2010). Mediterranean pines were also able to grow faster despite they reduced soil moisture more than the mountain 
and boreo-alpine pines (Figure S1). Taken all together, our results indicate that Mediterranean pines avoid summer drought maximizing their growth during the wet and cool season, accessing rapidly deep water reserves and exploring a large soil volume (Jackson et al. 1996; Schulze et al. 1996; Padilla and Pugnaire 2007). We suspect that these pines also avoid drought because of early emergence: they disperse seeds in the summer and most seedlings emerge in autumn (Calama et al. 2017). This early emergence in the wet season, together with fast growth and higher root growth under cool air conditions, likely facilitates seedling establishment long before the onset of summer drought. In contrast, the two mountain pine species in our study disperse seeds in winter, and seedlings emerge in spring (Castro 2006; Tíscar and Linares 2011). This later emergence in the wet season, together with lower growth capacity, results in less root growth prior to summer drought and therefore greater seedling vulnerability to water stress (Castro 2006; De Luis et al. 2008).

Mediterranean pines showed shorter SRL than mountain pines. In other words, the mountain and boreo-alpine pines grew longer roots per root mass unit invested, which does not support our initial hypothesis. Körner and Renhardt (1987) reported that that perennial herb species that grow at low altitude had thicker fine roots and lower SRL than perennial herbs species inhabiting at high altitude location. Differences in SRL allows for coping with changes in soil resources. SRL variability reflects a trade-off between stress tolerance and resource exploitation (Comas and Eissenstat 2004; de la Riva et al. 2017): fast growing species, which usually thrive in rich resource environments, are expected to have higher SRL, whereas slow growing, stress-tolerant species are expected to have lower SRL. However, whether root traits are primarily aligned along the acquisition-conservation axis is under debate (de la Riva et al. 2016; Kramer-Walter et al. 2016; de la Riva et al. 2017). Our data show that although Mediterranean pines inhabit drier locations they have lower SRL but higher growth rates than mountain and boreo-alpine pines. The high SRL in mountain and boreo-alpine pines is 
consistent with the idea from recent global reviews that plants inhabiting low-temperature ecosystems tend to have higher SRL (Freschet et al. 2017; Valverde-Barrantes et al. 2017). High SRL in cold-climate plants may be an adaptation to enhance soil nutrient exploitation, counteracting the negative effects of low temperature on organic matter mineralization (Comas et al. 2012).

Plants can also maintain their water status through increased biomass allocation to roots (Grossnickle 2005; Brunner et al. 2015). However, we found no significant R/S differences among species, suggesting a conservative pattern in the allocation of biomass among pine species. These results contrast with previous reports of higher R/S in P. nigra and P. sylvestris than in our Mediterranean pines (Climent et al. 2011; Matías et al. 2017). Differences between our study and previous ones may reflect that our study used a much larger rooting volume (Poorter et al. 2012a): in our study it was 360L, compared to 7L in Climent et al. (2011) or 2.5L in Matías et al. (2017). Similarly, our data showed no inter-species differences in the distribution of root mass through depth, in contrast to quantitative reviews and experimental studies showing that tree species adapted to dry conditions generally invest more root mass in depth than species inhabiting mesic environments (Schenk and Jackson 2002; Mokany et al. 2006; Markesteijn and Poorter 2009; Poorter et al. 2012b). It is possible that root depth and root system size are more important than R/S for survival under dry conditions (Padilla and Pugnaire 2007). Plants can also respond to water stress by constructing root systems with a larger taproot and increasing the allocation of biomass to coarse roots at the expenses of fine roots. It is also possible that our results are phylogenetically biased: the species in our study belong to the same genus, and morphological root traits are phylogenetically structured (Valverde-Barrantes et al. 2017). Indeed, Pinus species show a strong phylogenetic signal in some functional traits (He et al. 2012) and mass allocation may also have evolved conservatively. 
In conclusion, seedlings of southern Europe pines differ in how rapidly they grow and colonize the soil profile, and the sensitivity of root growth to low temperature. Mediterranean pines showed faster growth rates, larger root systems, faster rooting through the soil depth and

390 at lower temperature and soil moisture than mountain and boreo-alpine pines under lowland Mediterranean conditions. These differences related to the aridity to which the species are normally exposed in their range. SRL was higher in mountain and boreo-alpine pines than in Mediterranean pines. The distribution of root mass through soil depth and the ratio of mass allocation to roots and shoots did not differ among pines. Our results suggest that differences in growth rate play an important role in determining the capacity of pine species to colonize dry Mediterranean locations. However, other functional attributes related to plant's water economy and tolerance to high temperatures might also contribute to explain pine species distribution and should be addressed in future studies. Climate change projections for southern Europe predict an increase in aridity over the next century (Christensen and Christensen 2007), which can potentially trigger shifts in the tree species distribution. Based on our results, the higher growth capacity of Mediterranean pines may allow the colonization of zones at higher altitude and thereby displace mountain pines, which are also more vulnerable to warming and drought (Matías et al. 2017; Salazar-Tortosa et al. 2018).

\section{References}

Alía Miranda R, García del Barrio, J.M. Iglesias Sauce S, Mancha Núñez JA, de Miguel y del Ánge, 1 J. Nicolás Peragón JL, Pérez Martín F, Sánchez de Ron D (2009) Regiones de procedencia de especies forestales españolas. Organismo Autónomo de Parques Nacionales, Madrid, Spain.

Alsina MM, Smart DR, Bauerle T, De Herralde F, Biel C, Stockert C, Negron C, Save R (2011) Seasonal changes of whole root system conductance by a drought-tolerant grape 
root system. J Exp Bot 62:99-109 . doi: 10.1093/jxb/erq247

413 Alvarez-Uria P, Körner C (2007) Low temperature limits of root growth in deciduous and evergreen temperate tree species. Funct Ecol 21:211-218

415

416

417

418

419

420

421

422

423

424

425

426

427

Barbero M, Loisel R, Quezel P, Richardson DM, Romane F, Barbéro M, Loisel P, Quézel P, Richardson DM, Romane F (1998) Pines of the Mediterranean Basin. In: Richardson DM (ed) Ecology and biogeography of Pinus. Cambridge University Press, Cambridge, pp 153-170

Blanco E, Casado MA, Costa M, Escribano R, García M, Génova M, Gómez A, Gómez F, Moreno JC, Morla C, Regato P, Sainz H (1998) Los bosques Ibéricos. Una interpretación geobotánica . Editorial Planeta S.A., Barcelona

Brodribb TJ, McAdam SAM, Jordan GJ, Martins SC V (2014) Conifer species adapt to lowrainfall climates by following one of two divergent pathways. Proc Natl Acad Sci U S A 111:14489-93 . doi: 10.1073/pnas.1407930111

Brum M, Teodoro GS, Abrahão A, Oliveira RS (2017) Coordination of rooting depth and leaf hydraulic traits defines drought-related strategies in the campos rupestres, a tropical montane biodiversity hotspot. Plant Soil. doi: 10.1007/s11104-017-3330-x

Brunner I, Herzog C, Dawes MA, Arend M, Sperisen C (2015) How tree roots respond to drought. Front Plant Sci 6:1-16 . doi: 10.3389/fpls.2015.00547

Burdett AN (1990) Physiological processes in plantation establishment and the development of specifications for forest planting stock. Can J For Res 20:415-427

Burnham KP, Anderson DR (2002) Model Selection and Multimodel Inference: a Practical Information-theoretic Approach

Calama R, Manso R, Lucas-Borja ME, Espelta JM, Piqué M, Bravo F, del Peso C, Pardos M (2017) Natural regeneration in iberian pines: A review of dynamic processes and proposals for management. For. Syst. 26 
Canadell J, Jackson R, Ehleringer J, Mooney HA, Sala OE, Schulze E-D (1996) Maximum rooting depth of vegetation types at the global scale. Oecologia 108:583-595 . doi: 10.1007/BF00329030

Castro J (2006) Short delay in timing of emergence determines establishment success in Pinus sylvestris across microhabitats. Ann Bot 98:1233-1240 . doi: 10.1093/aob/mcl208

Castro J, Zamora R, Hodar JA, Gomez JM (2004) Seedling establishment of a boreal tree species (Pinus sylvestris) at its southernmost distribution limit: consequences of being in a marginal Mediterranean habitat. J Ecol 92:266-277 . doi: 10.1111/j.00220477.2004.00870.x

Chaves MM, Maroco JP, Pereira JS (2003) Understanding plant responses to drought-from genes to the whole plant. Funct Plant Biol 30:239-264.

Christensen JH, Christensen OB (2007) A summary of the PRUDENCE model projections of changes in European climate by the end of this century. Clim. Change 81:7-30

Climent J, Costa e Silva F, Chambel MR, Pardos M, Almeida MH (2009) Freezing injury in primary and secondary needles of Mediterranean pine species of contrasting ecological niches. Ann For Sci 66:407-407 doi: 10.1051/forest/2009016

Climent J, San-Martín R, Chambel MR, Mutke S (2011) Ontogenetic differentiation between Mediterranean and Eurasian pines (sect. Pinus) at the seedling stage. Trees - Struct Funct 25:175-186. doi: 10.1007/s00468-010-0496-8

Comas LH, Becker SR, Cruz VM V., Byrne PF, Dierig DA (2013) Root traits contributing to plant productivity under drought. Front Plant Sci 4:442 . doi: 10.3389/fpls.2013.00442

Comas LH, Eissenstat DM (2004) Linking fine root traits to maximum tree species rate among 11 mature temperate. Funct Ecol 18:388-397

Comas LH, Mueller KE, Taylor LL, Midford PE, Callahan HS, Beerling DJ (2012) Evolutionary patterns and biogeochemical significance of angiosperm root traits. Int $\mathrm{J}$ 
Cuesta B, Villar-Salvador P, Puértolas J, Jacobs DF, Rey Benayas JM (2010) Why do large, nitrogen rich seedlings better resist stressful transplanting conditions? A physiological analysis in two functionally contrasting Mediterranean forest species. For Ecol Manage 260:71-78 . doi: 10.1016/j.foreco.2010.04.002

De Herralde F, Savé R, Aranda X, Biel C (2010) Grapevine roots and soil environment: Growth, distribution and function. In: Methodologies and Results in Grapevine Research. Springer Netherlands, Dordrecht, pp 1-20

de la Riva EG, Marañón T, Pérez-Ramos IM, Olmo M, Villar R (2017) Plant and Soil Root traits across environmental gradients in Mediterranean woody communities : are they aligned along a single acquisition-conservation axis ? Plant Soil in press: . doi: 10.1007/s11104-017-3433-4

de la Riva EG, Tosto A, Pérez-Ramos IM, Navarro-Fernández CM, Olmo M, Anten NPR, Marañón T, Villar R (2016) A plant economics spectrum in Mediterranean forests along environmental gradients: Is there coordination among leaf, stem and root traits? J Veg Sci 27:187-199 . doi: 10.1111/jvs.12341

De Luis M, Verdú M, Raventós J (2008) Early to rise makes a plant healthy, wealthy, and wise. Ecology 89:3061-3071

De Micco V, Aronne G (2012) Morpho-anatomical traits for plant adapatation to drought. In: Aroca R (ed) Plant responses to drought stress: From morphological to molecular features. Springer-Verlag Berlin Heidelberg

Fernández L, Villar-Salvador P, Martínez-Vilalta J, Toca AO, Zavala MA (2017) Distribution of pines in Europe agrees with seedling differences in foliage frost tolerance, not with xylem embolism vulnerability. Tree Physiol in press:

Freschet GT, Valverde-Barrantes OJ, Tucker CM, Craine JM, McCormack ML, Violle C, 
Fort F, Blackwood CB, Urban-Mead KR, Iversen CM, Bonis A, Comas LH, Cornelissen JHC, Dong M, Guo D, Hobbie SE, Holdaway RJ, Kembel SW, Makita N, Onipchenko VG, Picon-Cochard C, Reich PB, de la Riva EG, Smith SW, Soudzilovskaia NA, Tjoelker MG, Wardle DA, Roumet C (2017) Climate, soil and plant functional types as drivers of global fine-root trait variation. J Ecol 105:1182-1196 . doi: 10.1111/13652745.12769

Gonzalo J (2008) Diagnosis fitoclimática de la España peninsular. Actualización y análisis geoestadístico aplicado. Universidad Politécnica de Madrid

Grossnickle SC (2012) Why seedlings survive: influence of plant attributes. New For 43:711738

Grossnickle SC (2005) Importance of root growth in overcoming planting stress. New For 30:273-294 . doi: 10.1007/s11056-004-8303-2

He T, Pausas JG, Belcher CM, Schwilk DW, Lamont BB (2012) Fire-adapted traits of Pinus arose in the fiery Cretaceous. New Phytol 194:751-759 . doi: 10.1111/j.14698137.2012.04079.x

Hernández EI, Vilagrosa A, Pausas JG, Bellot J (2010) Morphological traits and water use strategies in seedlings of Mediterranean coexisting species. Plant Ecol 207:233-244 . doi: $10.1007 / \mathrm{s} 11258-009-9668-2$

Holmgren M, López BC, Gutiérrez JR, Squeo FA (2006) Herbivory and plant growth rate determine the success of El Niño Southern Oscillation-driven tree establishment in semiarid South America. Glob Chang Biol 12:2263-2271 . doi: 10.1111/j.13652486.2006.01261.x

Jackson RB, Canadell J, Ehleringer JR, Mooney HA, Sala OE, Schulze ED (1996) A global analysis of root distributions for terrestrial biomes. Oecologia 108:389-411 . doi: 10.1007/BF00333714 
Körner CH, Renhardt U (1987) Dry matter partitioning and root length/leaf area ratios in herbaceous perennial plants with diverse altitudinal distribution. Oecologia 74:411-418

Kramer-Walter KR, Bellingham PJ, Millar TR, Smissen RD, Richardson SJ, Laughlin DC (2016) Root traits are multidimensional: specific root length is independent from root tissue density and the plant economic spectrum. J Ecol 104:1299-1310 . doi:

$$
10.1111 / 1365-2745.12562
$$

Levitt J (1980) Responses of plants to environmental stresses. Volume II. Water, radiation, salt, and other stresses, 2nd edn. Academic Press, New York

Lyr H (1996) Effect of the root temperature on growth parameters of various European tree species. In: Annales des sciences forestières. EDP Sciences, pp 317-323

Markesteijn L, Poorter L (2009) Seedling root morphology and biomass allocation of 62 tropical tree species in relation to drought- and shade-tolerance. J Ecol 97:311-325 . doi:

$$
10.1111 / \mathrm{j} .1365-2745.2008 .01466 . x
$$

Matías L, Castro J, Villar-Salvador P, Quero JL, Jump AS (2017) Differential impact of hotter drought on seedling performance of five ecologically distinct pine species. Plant Ecol 218:201-212 . doi: 10.1007/s11258-016-0677-7

Matías L, González-Díaz P, Jump AS (2014) Larger investment in roots in southern rangeedge populations of Scots pine is associated with increased growth and seedling resistance to extreme drought in response to simulated climate change. Environ Exp Bot $105: 32-38$

Mitrakos K (1980) A theory for Mediterranean plant life. Acta Oecologica Oecologia Plant $1: 245-252$

Mokany K, Raison RJ, Prokushkin AS (2006) Critical analysis of root: Shoot ratios in terrestrial biomes. Glob Chang Biol 12:84-96 . doi: 10.1111/j.1365-2486.2005.001043.x

Ostonen I, Püttsepp Ü, Biel C, Alberton O, Bakker MR, Lõhmus K, Majdi H, Metcalfe D, 
Olsthoorn AFM, Pronk A, Vanguelova E, Weih M, Brunner I (2007) Specific root length as an indicator of environmental change. Plant Biosyst 141:426-442 . doi:

\section{$10.1080 / 11263500701626069$}

Padilla FM, Pugnaire FI (2007) Rooting depth and soil moisture control Mediterranean woody seedling survival during drought. Funct Ecol 21:489-495

Poorter H, Bühler J, Van Dusschoten D, Climent J, Postma J a. (2012a) Pot size matters: A meta-analysis of the effects of rooting volume on plant growth. Funct Plant Biol 39:839850 . doi: 10.1071/FP12049

Poorter H, Niklas KJ, Reich PB, Oleksyn J, Poot P, Mommer L (2012b) Biomass allocation to leaves, stems and roots: meta-analyses of interspecific variation and environmental control. New Phytol 193:30-50 . doi: 10.1111/j.1469-8137.2011.03952.x

Pregitzer KS, King JS, Burton AJ, Brown SE (2000) Responses of tree fine roots to temperature. New Phytol 147:105-115

Pulido F, García E, Obrador JJ, Moreno G (2010) Multiple pathways for tree regeneration in anthropogenic savannas: incorporating biotic and abiotic drivers into management schemes. J Appl Ecol 47:1272-1281 . doi: 10.1111/j.1365-2664.2010.01865.x

Reich PB, Tjoelker MG, Walters MB, Vanderklein DW, Buschena C (1998) Close association of RGR, leaf and root morphology, seed mass and shade tolerance in seedlings of nine boreal tree species grown in high and low light. Funct Ecol 12:327-338

Richter S, Kipfer T, Wohlgemuth T, Guerrero CC, Ghazoul J, Moser B (2012) Phenotypic plasticity facilitates resistance to climate change in a highly variable environment. Oecologia 169:269-279

Ruiz-Benito P, Gómez-Aparicio L, Zavala MA (2012) Large-scale assessment of regeneration and diversity in Mediterranean planted pine forests along ecological gradients. Divers Distrib 18:1092-1106 . doi: 10.1111/j.1472-4642.2012.00901.x 
Salazar-Tortosa D, Castro J, De Casas RR, Viñegla B, Sánchez-Cañete EP, P. Villar-Salvador P (2017) Gas exchange at whole plant level shows that a less conservative water use is linked to a higher performance in three ecologically distinct pine species. Environ Res Lett in press:

Salazar-Tortosa D, Castro J, Villar-Salvador P, Viñegla B, Matías L, Michelsen A, Rubio de Casas R, Querejeta JI (2018) The "isohydric trap": A proposed feedback between water shortage, stomatal regulation, and nutrient acquisition drives differential growth and survival of European pines under climatic dryness. Glob Change Biol, in press.

Schenk HJ, Jackson RB (2002) Rooting depths, lateral root spreads and belowground aboveground allometries of plants in water limited ecosystems. JEcol 480-494 . doi: 10.1046/j.1365-2745.2002.00682.x

Schulze ED, Mooney HA, Sala OE, Jobbagy E, Buchmann N, Bauer G, Canadell J, Jackson RB, Loreti J, Oesterheld M, Ehleringer JR (1996) Rooting depth, water availability, and vegetation cover along an aridity gradient in Patagonia. Oecologia 108:503-511

Stella JC, Battles JJ (2010) How do riparian woody seedlings survive seasonal drought? Oecologia 164:579-590. doi: 10.1007/s00442-010-1657-6

Tíscar PA, Linares JC (2011) Structure and regeneration patterns of Pinus nigra subsp. Salzmannii natural forests: A basic knowledge for adaptive management in a changing climate. Forests 2:1013-1030 . doi: 10.3390/f2041013

Toca AO, Oliet JA, Villar-Salvador P, Maroto J, Jacobs DF (2017) Species ecology determines the role of nitrogen nutrition on the frost tolerance of pine seedlings. Tree Physiol in press:

Valverde-Barrantes OJ, Freschet GT, Roumet C, Blackwood CB (2017) A worldview of root traits: The influence of ancestry, growth form, climate and mycorrhizal association on the functional trait variation of fine-root tissues in seed plants. New Phytol 215:1562- 
588 Vicente-Serrano SM, Gouveia C, Camarero JJ, Begueria S, Trigo R, Lopez-Moreno JI, Azorin-Molina C, Pasho E, Lorenzo-Lacruz J, Revuelto J, Moran-Tejeda E, SanchezLorenzo A (2013) Response of vegetation to drought time-scales across global land biomes. Proc Natl Acad Sci 110:52-57 . doi: 10.1073/pnas.1207068110

592 Villar-Salvador P, Puértolas J, Cuesta B, Peñuelas JL, Uscola M, Heredia-Guerrero N, Rey

593 Benayas JM (2012) Increase in size and nitrogen concentration enhances seedling survival in Mediterranean plantations. Insights from an ecophysiological conceptual 


\section{Figure legends}

Figure 1: Root mass of pine species at the end of the experiment over the entire soil depth (a) and in layers at depths of 0-40 cm (b), 40-80 cm (c), and 80-110 cm (d). Boxes show the 95\% and $5 \%$ percentile values, while the solid line indicates the median. Different letters show significant differences $(p<0.05)$ between pine species.

Figure 2: Total root length (a) and specific root length (b) of pine species at the end of the experiment. Boxes are the $95 \%$ and $5 \%$ percentile values, while the solid line indicates the median. Different letters show significant differences $(p<0.05)$ between pine species.

Figure 3: Root length at different soil depths in pine species. Lines depict the mean values $(n=6)$ for each species at each measurement date, while strips represent the SE. The scale of the root length axis differs among panels.

Figure 4: Relationship of pine species' scaled root length increment with temperature. Points show observed scaled root length increment. Lines depict the predictions of the fitted linear mixed model for each species, while strips represent the SE of these predictions.

Figure 5: Time needed for roots to reach a depth of $40 \mathrm{~cm}$ across pine species. Boxes are the 95\% and 5\% percentile values, while the solid lines indicate the median. Different letters show significant differences $(p<0.05)$ between pine species.

Figure 6: Relationships of a pine species' root mass at the end of the experiment, shoot diameter growth rate, specific root length (SRL) and time for roots to reach a depth of $40 \mathrm{~cm}$ with $2.5 \%$ percentile values of annual rainfall in the distribution range of that species. Equations of the adjusted linear models are shown together with $\mathrm{r}^{2}$ and $\mathrm{P}$ values. Each point represents mean values $\pm 1 \mathrm{SE} . \mathrm{Ph}=P$.halepensis, $\mathrm{Pa}=P$.pinea, $\mathrm{Ppt}=P$.pinaster, $\mathrm{Pn}=P$.nigra and $\mathrm{Ps}=P$. sylvestris . 
a) Whole profile $(0-110 \mathrm{~cm}$ depth)

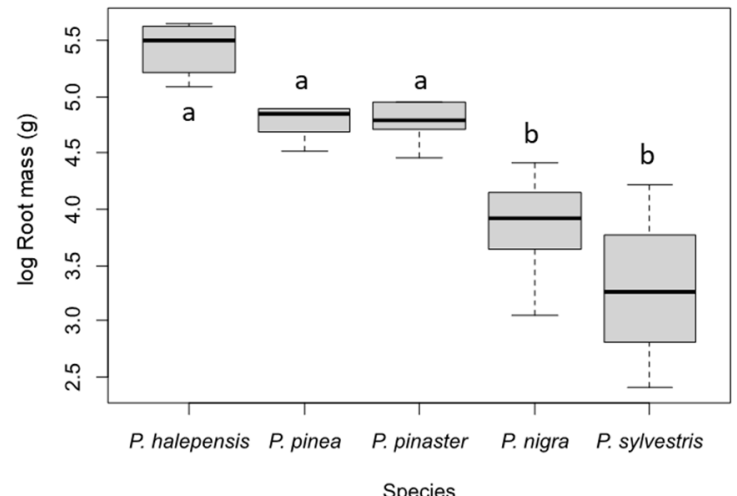

c) $40-80 \mathrm{~cm}$ depth

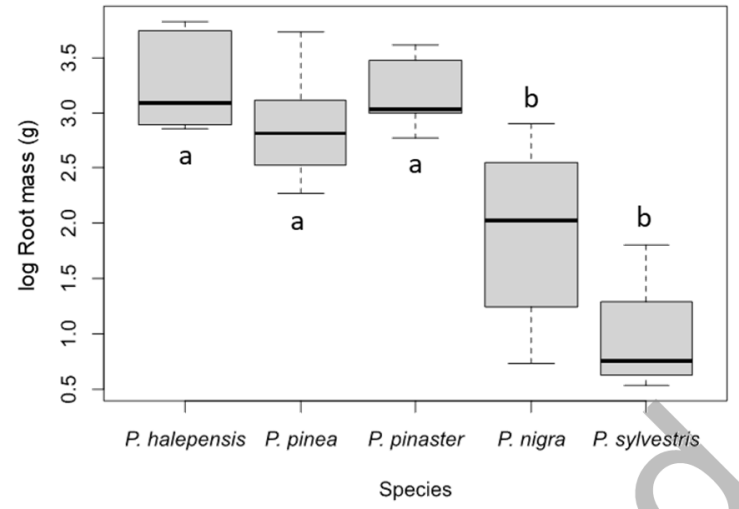

\section{b) $0-40 \mathrm{~cm}$ depth}

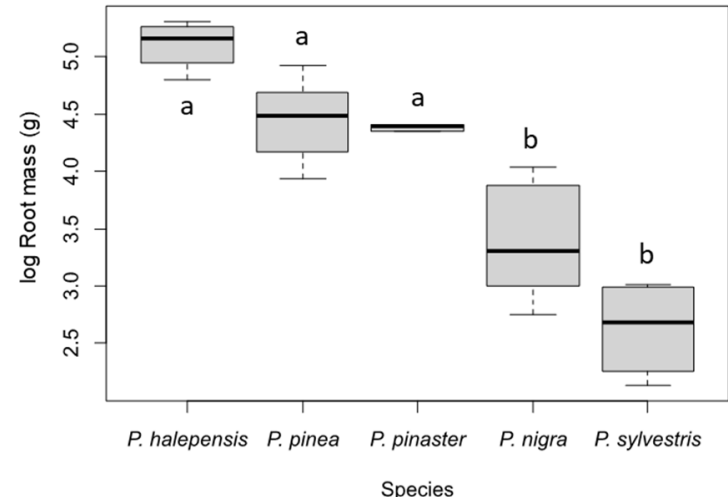

d) $80-110 \mathrm{~cm}$ depth

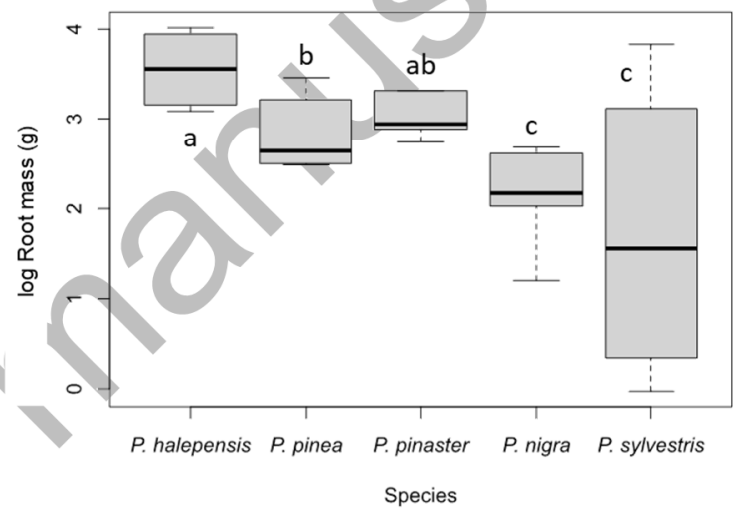

Figure 1 
a)

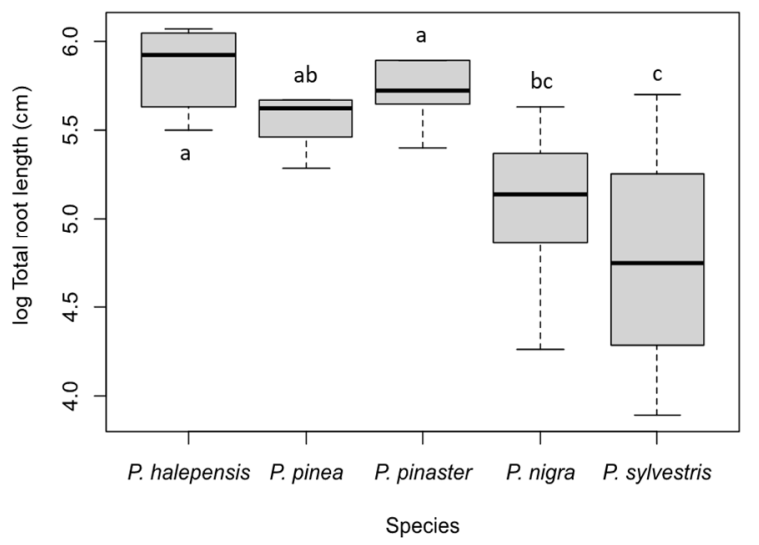

b)

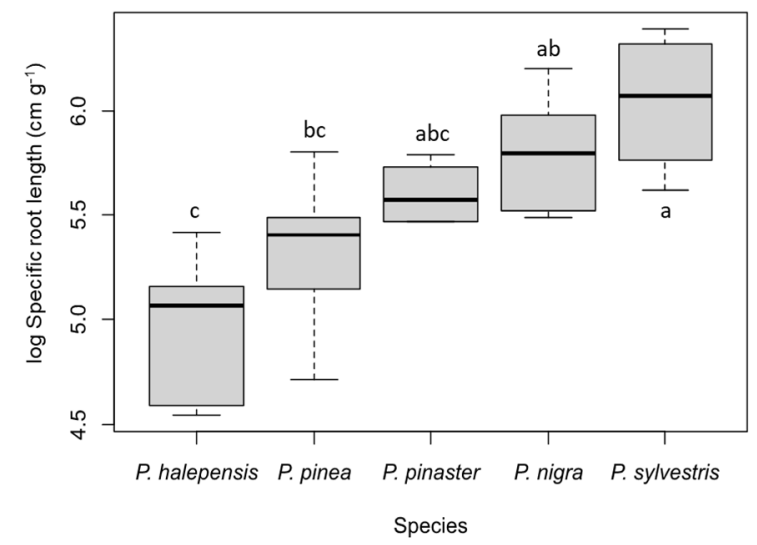

628

Figure 2 


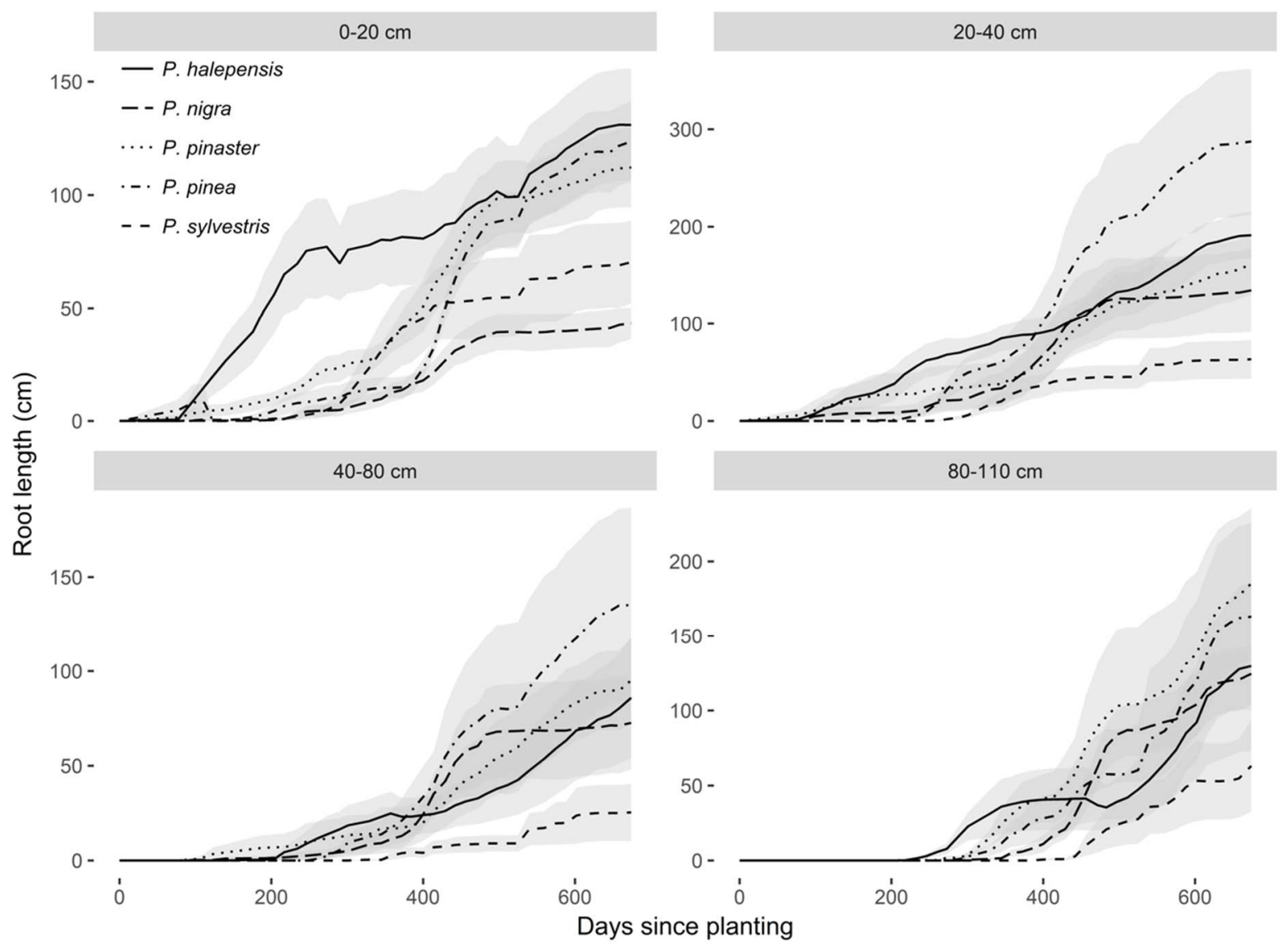

631

Figure 3

633 


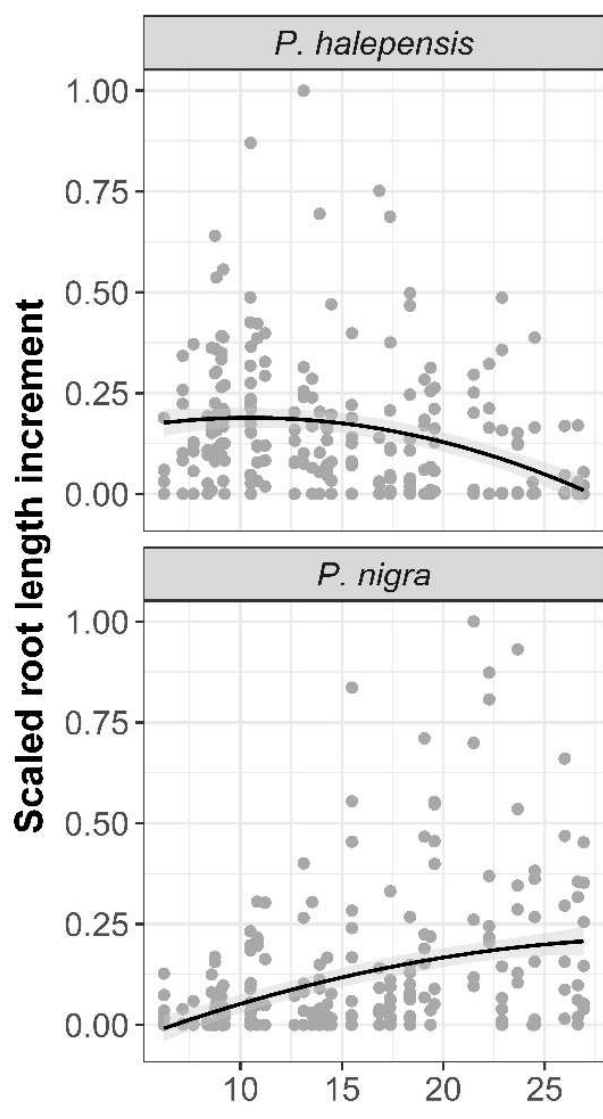

634

635

636
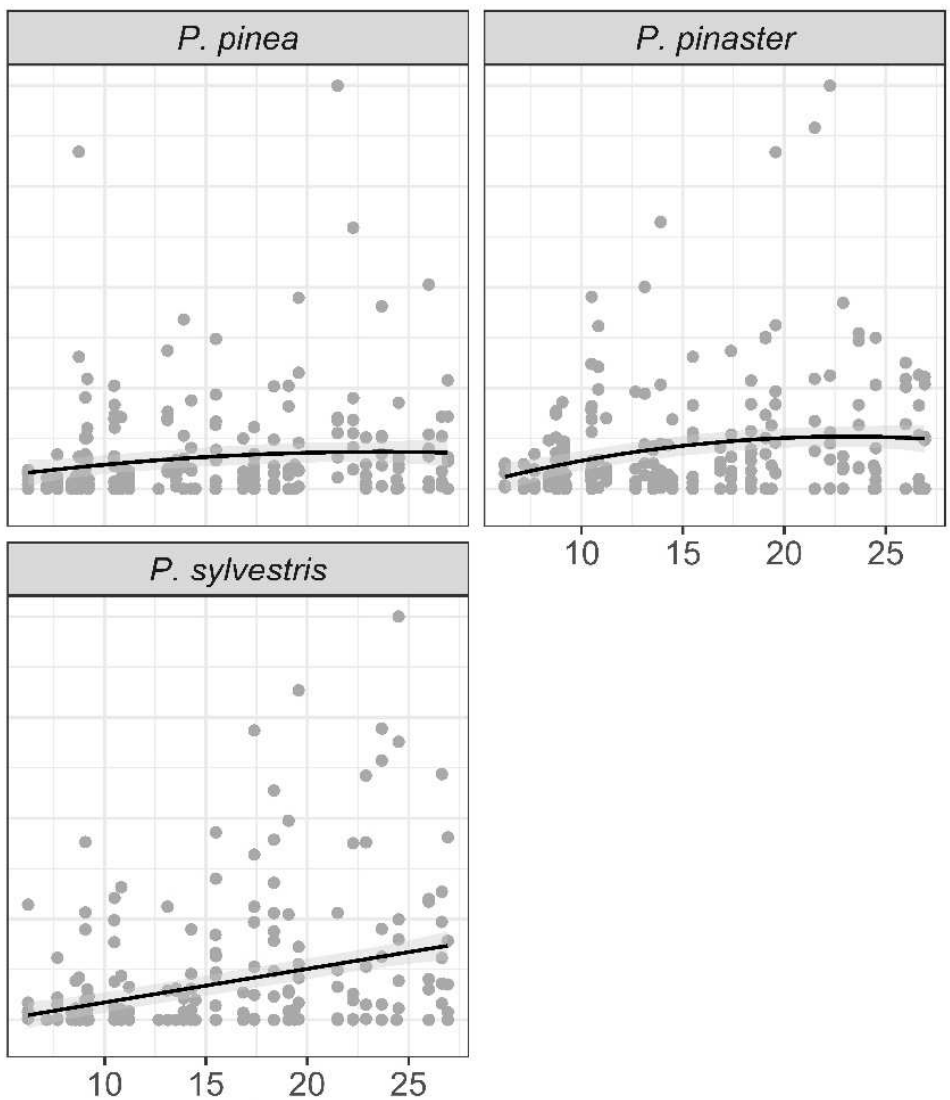

Temperature $\left({ }^{\circ} \mathrm{C}\right)$

Figure 4 


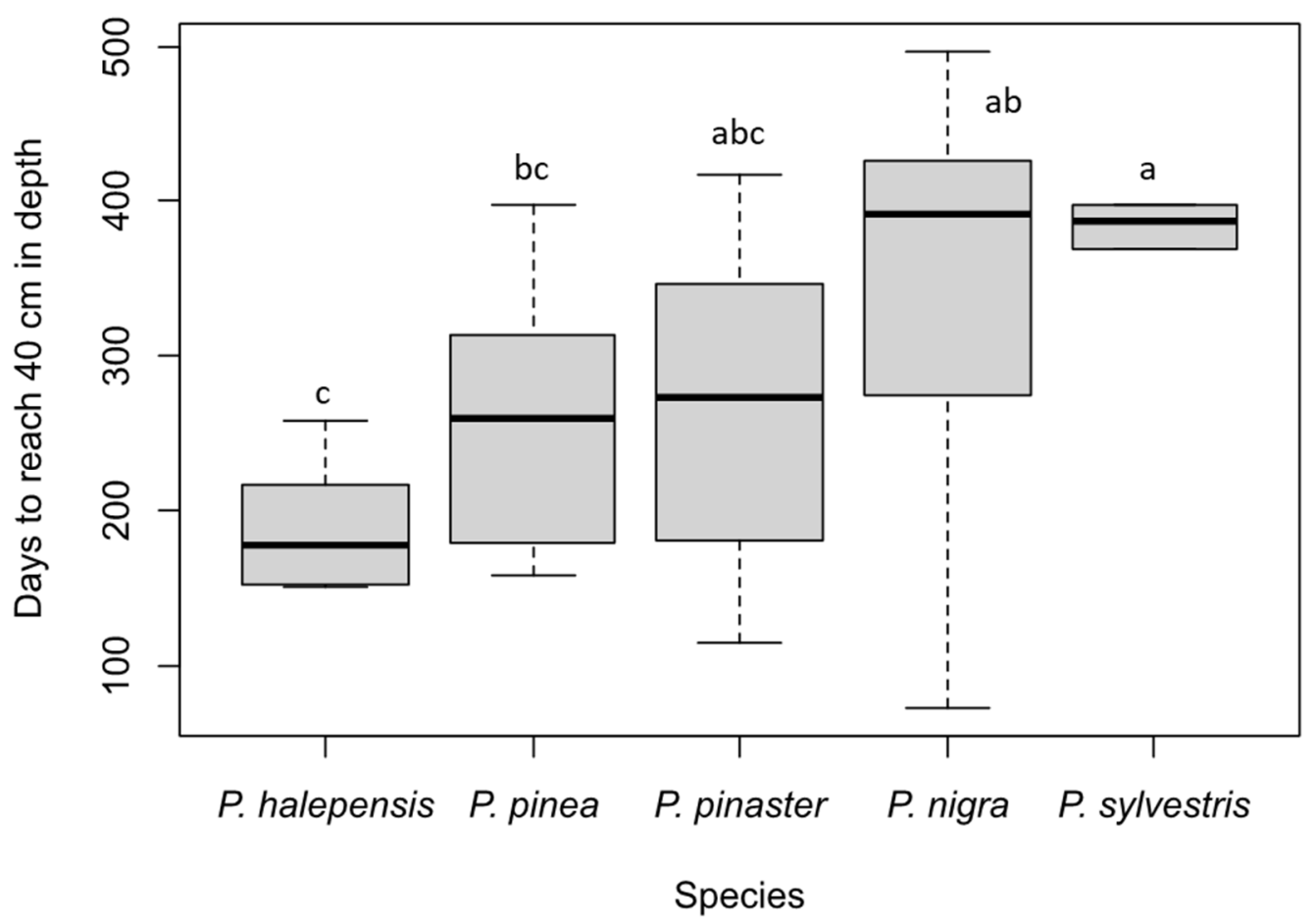

638

Figure 5 


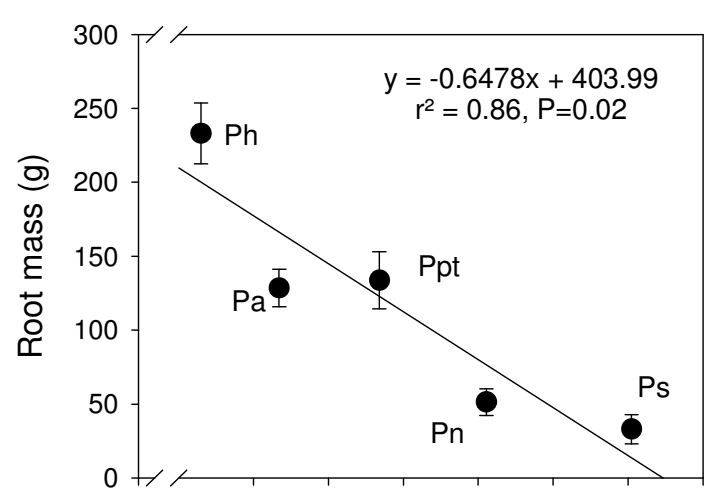

$\frac{0}{x}$
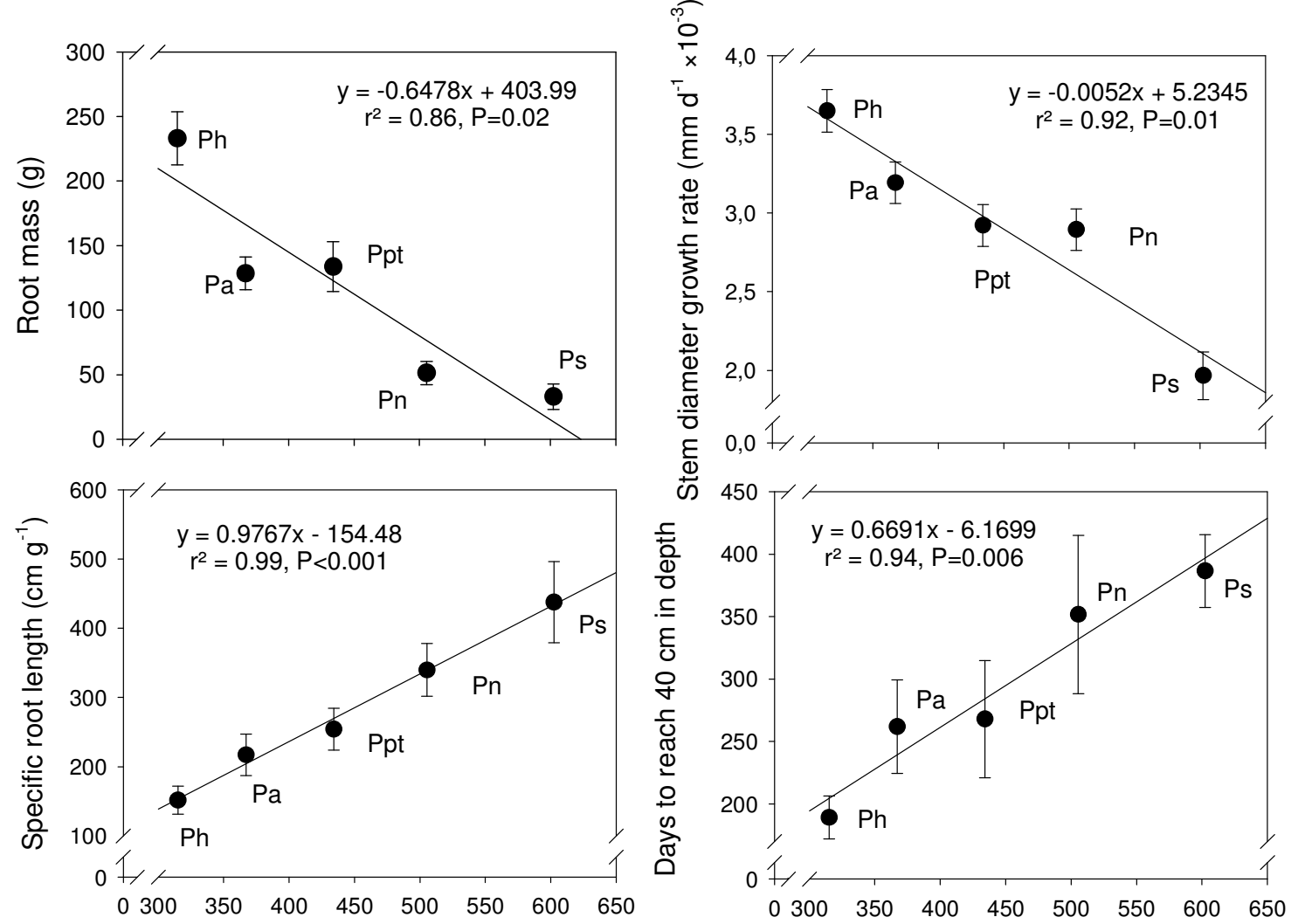

Annual rainfall of the $2.5 \%$ driest locations $(\mathrm{mm})$

Annual rainfall of the $2.5 \%$ driest locations $(\mathrm{mm})$ 